\title{
The Analysis of Stress Levels of the Female Wrestlers Studying in Higher Education (A Case of Batman Provice)
}

\author{
Nevzat DİNÇER ${ }^{1} \bowtie$ \\ Zühal KILINÇ ${ }^{2}$
}

1,2 Batman University, Batman, Turkey Email: zuhalkilinc14@gmail.com Email:nevaatdincer@gmail.com

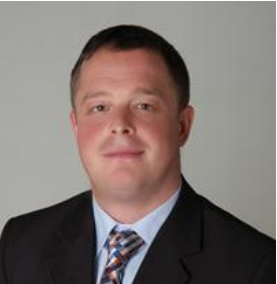

\begin{abstract}
The purpose of this paper was to analyze the stress levels of the female wrestlers studying in higher education. The trial group of the research consisted of 52 volunteer female wrestlers studying in higher education in the province Batman. The research data were collected with "Work Stress Scale" developed by House and Rizzo (1972) adapted into Turkish by Yalçın (2009). In the analysis of data, the Mann Whitney-U and Kruskall Wallis-H tests were benefited from as well as the descriptive statistical techniques. As a result of the research, the female wrestlers were considered to experience stress occasionally. While there were not any differences in the female wrestlers' stress levels in accordance with the variables of bachelor year, persons who they live and income status, there were some differences in their stress levels about whether family members were keen on sport or not.
\end{abstract}

Keywords: Wrestling, Female wrestler, Stress levels, Education.

Citation | Nevzat DİNÇER; Zühal KILINÇ (2018). The Analysis of Stress Levels of the Female Wrestlers Studying in Higher Education (A Case of Batman Provice). Asian Journal of Education and Training, 4(2): 156-160.

History:

Received: 8 March 2018

Revised: 13 April 2018

Accepted: 18 April 2018

Published: 23 April 2018

Licensed: This work is licensed under a Creative Commons Attribution 3.0 License (c))

Publisher:Asian Online Journal Publishing Group
Contribution/Acknowledgement: Both authors contributed to the conception and design of the study.

Funding: This study received no specific financial support

Competing Interests: The authors declare that they have no conflict of interests.

Transparency: The authors confirm that the manuscript is an honest, accurate, and transparent account of the study was reported; that no vital features of the study have been omitted; and that any discrepancies from the features of the study have been omitted
study as planned have been explained.

Ethical: This study follows all ethical practices during writing.

\section{Contents}

1. Introduction

3. Findings 158

4. Conclusion and Discussion.

References 


\section{Introduction}

Stress has been regarded as a disease of modern societies. Stress, which has become a part of daily life, has been experienced even without awareness by many people now (Güçlü, 2001). The stress concept, which shows itself almost in each part of our lives, direct us towards different images in physical, mental and psychological aspects. That's why, it is not possible to isolate stress from our lives (Bozkurt et al., 2010).

Today in modern societies, especially in ultimately developed and so complex organizations it is not likely for people to live without stress. People spend most of their lives on thinking about work and work-related activities. This situation necessarily allows them suffer from negative physical and psychological factors in work process or issues following work process. In this age we live, individuals become isolated day by day, only a sense of achievement prevails, this also pulls people into depression and stress. Stress is a situation of tension in individuals resulting from extraordinary demands, pressures or opportunities (Schermerborn et al., 1988). Stress is a reaction to differences between a person's real life and expectations (Magnuson, 1990). Stress is defined as a result of opportunities, limitations or demands encountered by persons, it represents unclear and prominent dynamic conditions (Robins, 1996).

Individuals go into deliberative actions in order to fulfill their physical, psychological and social needs. When we face with tension-leading conditions, our body tries to adapt to this situation with some reactions. When human existence having biological balance in homeostatic limits is confronted with stress stimulus from internal or external environment, it reacts making physiological or psychological defenses. Stress reaction has short life. It urgently gives energy required by an organism. If there is any time to refresh oneself between two stressful events following each other, all is well. But today increasing life tempo without stopping and stressful situations following each other create continuously growing stimulation and liveliness in us. This situation may make an individual feel psychologically uneasy, more frustrated and inclined to make fault. It is necessary to reveal personal reactions to individual and changing stress situations in accordance with beliefs, habits, personalities and body structures as soon as possible. If stress reaction has a rising tendency for a long time, this situation may cause various physical damages as well. Reactions in individuals by stress are analyzed in three titles; non-specific reactions, general harmonisation syndrome and fight or flight reaction (Makin and Lindley, 1995).

Stress is a phenomenon that can be perceived and experienced according to many variables. Economic, social, cultural, organizational, individual and demographic reasons as well as work and working environment, economic and political progress of the country, family structure, life conditions etc. there are many stressful factors. It is important to try to understand these from different angles to understand the stress-generating capacity of each factor (Ayşen, 2015).

Stress-related researches primarily focused on the effects of stress, started with a view to getting rid of the negative effects of stress. In time stress was regarded to have many reasons and a series of results, stress was considered to be a physiological and psychological event which was researched more and more. When any type of stress is confronted, reactions by an organism vary depending on various factors. These are stress and individual characteristics. An individual's age, gender are among these factors and stress-leading situations and its own effects vary from each other, depending on an individual's development characteristics (Durmus and Asçığlu, 2005). Education background, world viewpoints, opinions about the relevant events may affect the volume of stress experience. Because life philosophies, which occur following individuals' beliefs, life experiences and education backgrounds, let them assess events in different ways (Arık, 1996). From this point of view, each person' stress load varies from each other to take. To some extent, when success rates go up, individuals' stress levels rise as well. At this point, it is not possible to consider success as an undesirable result. Success is the greatest prize for the active person. Stress may have positive-negative effects on persons, however, work stress-related researches have focused on negative effects more (Arık, 1996).

Now most of athletes are witnessed to attribute different and wrong meanings to stress, a current concept in psychology. Stress is perceived in sport community and among athletes in negative ways. Furthermore, it is necessary not to ignore that the stress concept is beneficial in current conditions. In the light of psychological and psychosomatic syndromes, stress affecting individual performance in various levels among athletes, the following questions were searched for answers within this paper aimed at the analysis of stress levels of the female wrestlers studying in higher education;

1-At which levels do the female wrestlers experience stress?

2- Do the female wrestlers' stress levels significantly differ in the variables of bachelor's year, persons they live with, existence of persons interested in sport in their families and family income levels.

\section{Method}

\section{1. Research Design}

This research was designed with the descriptive screening model aimed at analyzing the stress levels of the female wrestlers having education in higher education.

\subsection{Study Group}

The trial group of the research consisted of 52 volunteer female wrestlers studying at higher education in the province Batman and wrestling.

\subsection{Data Analysis}

The research data were collected with "The Work Stress Scale" developed by House and Rizzo (1972) adapted into Turkish by Yalçın (2009). The scale involved two parts, 17 questions including 7 questions aimed at determining the personal characteristics of the female wrestlers in the first part, 10 questions aimed at determining the stress levels of the female wrestlers in the second part. The scale items were pointed with the five point likert scale as 1:Never, 2: Rarely, 3:Sometimes, 4:Often, 5:Very Often. 
The highest point from the scale was 50, the lowest point was 10 . Since the gap width of the scale was estimated as "range width/relevant group number", the average intervals for the findings were; (1.01-1.80) Never, (1.81-2.60) Rarely, (2.61-3.40) Sometimes, (3.41-4.20) Often, (4.21-5.00) Very Often. The Cronbach Alpha internal consistency coefficient of the scale was found to be .83 , so this scale was regarded to be reliable.

In the analysis of data, one sample test Kolmogorow Smirnov test was primarily applied for seeing whether data showed a normal distribution, thus data did not show any normal distribution $(\mathrm{z}=.090 ; \mathrm{p}<0.05)$. In this scope, Mann Whitney-U and Kruskall Wallis-H tests from non-parametrical tests were benefited from as well as the descriptive statistical techniques. In the interpretation of findings, the significance level was regarded to be $\mathrm{p}<0.05$.

\section{Findings}

Table-1. The Distributions of Personal Characteristics of Participants

\begin{tabular}{l|l|l}
\hline Bachelor Year & $\mathbf{N}$ & $\mathbf{\%}$ \\
\hline 1-2 Years & 34 & 65,4 \\
\hline 3-4 Years & 18 & 34,6 \\
\hline Who Do You Live With? & $\mathbf{N}$ & $\mathbf{\%}$ \\
\hline Family & 38 & 73,1 \\
\hline Club & 14 & 26,9 \\
\hline Are There Family Members Interested in Sport? & $\mathbf{N}$ & $\mathbf{\%}$ \\
\hline Yes & 17 & 32,7 \\
\hline No & 35 & 67,3 \\
\hline Family Income Status & $\mathbf{N}$ & $\mathbf{\%}$ \\
\hline 450 TL below & 13 & 25,0 \\
\hline 451 TL-850 TL & 11 & 21,2 \\
\hline 851 TL-1.250 TL & 13 & 25,0 \\
\hline 1.251 TL-2.000 TL & 8 & 15,4 \\
\hline 2.001 TL-3.000 TL & 7 & 13,5 \\
\hline Total & 52 & 100,0 \\
\hline
\end{tabular}

According to Table 1; of the female wrestlers, $65,4 \%$ (34 persons) had a bachelor degree of 1-2 years, $34,6 \%$ (18 persons) had a bachelor degree of 3-4 years. Of the female wrestlers, 32,7\% (17 persons) consisted of family members interested in sport, $67,3 \%$ (35 persons) did not have any family members interested in sport, $73,1 \%(38$ persons) lived with their families, $26,9 \%$ (14 persons) lived with their club members. In accordance with family income status, the income level was below $450 \mathrm{TL}$ in $25,0 \%$ (13 persons) between 451 TL-850 TL in $21,2 \%(11$ persons), between 851 TL-1.250 TL in 25,0\% (13 persons), between 1.251 TL-2.000 TL in 15,4\% (8 persons), between 2.001 TL-3.000 TL in 13,5\% (7 persons) among the female wrestlers.

Table-2. The Descriptive Statistical Results of Stress Levels of Participants

\begin{tabular}{l|l|l}
\hline Stress Level Items & $\boldsymbol{A v g}$. & $\boldsymbol{S S}$ \\
\hline $\begin{array}{l}\text { 1.How often did you feel unhappy when you experienced an unexpected event in the last } \\
\text { month? }\end{array}$ & 1,88 & 0,65 \\
\hline $\begin{array}{l}\text { 2. How often did you feel unhappy when you could not take important things under control } \\
\text { in your life in the last month? }\end{array}$ & 1,77 & 1,02 \\
\hline $\begin{array}{l}\text { 3. How often did you feel angry and stressful in the last month? } \\
\text { 4. How often did you feel self-confident in overcoming with your personal problems in the } \\
\text { last month? }\end{array}$ & 2,54 & 1,34 \\
\hline $\begin{array}{l}\text { 5. How often did you think that everything was OK in the last month? } \\
\text { 6. How often did you think that you could not do what you needed to do in the last month? }\end{array}$ & 2,13 & 1,13 \\
\hline $\begin{array}{l}\text { 7.How often did you take events which disturbed you, under control in the last month? } \\
\text { 8. How often did you feel yourself important in the last month? }\end{array}$ & 2,63 & 1,16 \\
\hline $\begin{array}{l}\text { 9. How often did you feel frustrated when you could not take events under control in the } \\
\text { last month? }\end{array}$ & 2,27 & 1,19 \\
\hline $\begin{array}{l}\text { 10.How often did you feel that difficulties accumulated and you could not overcome with } \\
\text { these difficulties in the last month? }\end{array}$ & 2,17 & 1,20 \\
\hline $\begin{array}{l}\text { Total } \\
\text { (1:Never, 2:Seldom, 3:Sometimes, 4:Often, 5:Very Often) }\end{array}$ & 2,31 & 1,13 \\
\hline
\end{tabular}

According Table 2, the female wrestlers' stress levels were generally regarded to be rarely $(2,31 \pm 1,13)$. In other words, the female wrestlers claimed to experience stress occassionally. When the female wrestlers' stress levels were analyzed, they could take the events which disturbed them, under control in their lives in the last month $(1,77 \pm 1,02)$, they did not feel unhappy when they were confronted with unexpected events $(1,88 \pm 0,65)$ but they could not occassionally do what they needed to do in the last month $(2,13 \pm 1,21)$, they could not overcome with difficulties when difficulties increasingly became more $(2,17 \pm 1,20)$, they felt more important than everything $(2,35 \pm 1,20)$, angry and frustrated $(2,58 \pm 1,04)$, they thought that everything was OK $(2,13 \pm 1,21)$, they rarely felt angry when they could not take some events under control $(2,27 \pm 1,19)$, they could control some events $(2,63 \pm 1,16)$, they felt self-confident in overcoming with their personal problems $(2,54 \pm 1,34)$. 
Table-3. The Mann Whitney-U Test Results of Their Stress Levels in Accordance with the Variables of Participants' Bachelor Year, Persons They Live with and Family Members Interested in Sport

\begin{tabular}{|c|c|c|c|c|c|}
\hline Bachelor Year & $\mathbf{N}$ & S.O. & S.T. & $\mathbf{U}$ & $\mathbf{P}$ \\
\hline $1-2$ Years & 34 & 28,53 & 970,00 & \multirow{3}{*}{237,000} & \multirow{3}{*}{0,18} \\
\hline $3-4$ Years & 18 & 22,67 & 408,00 & & \\
\hline Total & 52 & & & & \\
\hline Who Do You Live With? & $\mathbf{N}$ & S.O. & S.T. & $\mathbf{U}$ & $\mathbf{P}$ \\
\hline Family & 38 & 25,82 & $981, \mathrm{OO}$ & \multirow{3}{*}{240,000} & \multirow{3}{*}{0,59} \\
\hline Club & 14 & 28,36 & 397,00 & & \\
\hline Total & 52 & & & & \\
\hline Are There Family Members Interested in Sport? & $\mathbf{N}$ & S.O. & S.T. & $\mathbf{U}$ & $\mathbf{P}$ \\
\hline Yes & 17 & 35,21 & 598,50 & \multirow{3}{*}{149,500} & \multirow{3}{*}{$0,00^{*}$} \\
\hline No & 35 & 22,27 & 779,50 & & \\
\hline Total & 52 & & & & \\
\hline
\end{tabular}

According to Table 3, the female wrestlers' stress levels did not significantly differ in bachelor year and people they live with $(\mathrm{p}>0,05)$. However, the female wrestlers' stress levels significantly varied when there was any family member interested in sport $(\mathrm{p}<0,05)$. When the female wrestlers' mean ranks were assessed, the group involving individuals doing sport in family had higher stress levels.

Table-4. The Kruskall Wallis-H Test Results of Their Stress Levels in Accordance with the Variable of Participants' Family Income Level

\begin{tabular}{l|l|l|l|l|l}
\hline Income Level (TL) & N & S.O. & Chi-Square & df & P \\
\hline 450 below & 13 & 31,58 & & \\
\hline $451-850$ & 11 & 22,23 & & \multirow{2}{*}{0,33} \\
\hline $851-1250$ & 13 & 21,35 & & \\
\hline $1251-2000$ & 8 & 29,00 & & \\
\cline { 1 - 2 } $2001-3000$ & 7 & 30,50 & & & \\
\cline { 1 - 2 } Total & 52 & & & \\
\hline According to Table 4, the female wrestlers' stress levels did not significantly vary in family income levels $\left(\mathrm{X}^{2}=4,56 ; \mathrm{p}>0,05\right)$.
\end{tabular}

\section{Conclusion and Discussion}

This research was done to reveal the stress levels of the female wrestlers. In this research, the female wrestlers generally said to experience stress occasionally. The female wrestlers were observed to take events which disturbed them, under control in their lives in the last month and not to feel dissatisfied with the unexpected events they experienced but they had a few difficulties following each other, they could not overcome with these issues and achieve in these in the last month occassionally. This shows that the female wrestlers value themselves above everything, rarely feel angry and stressful and frustrated when some events occur beyond their control but yet they can keep events under control.

In the face of all these events, the female wrestlers were deemed to feel self-confident while overcoming with these personal problems. As long as an individual's capabilities for coping mean handling with stressful events, the person can stay away from high tension. But if the requirements of events are more serious and the person has difficulty in adapting to these requirements, unbalanced situations occur and bodies undertake any responsibilities over physical and psychological carrying capacities. An individual may take these heavy responsibilities to some extent. But if this situation goes on, signs of excessive stress show up, burnout syndrome or stress-related diseases follow these signs (Gülbeyaz, 2006).

There was a statistically significant and positive relationship between self-interpretation stressors and physical stressors, desperate approach, submissive approach, and social support seeking. There was a statistically significant and negative correlation between stressors and self- a relationship has been identified (Nesrin, 2016).

Furthermore, the participants suggested to feel self-confident in overcoming with their personal problems. This situation may be related with the female wrestlers' sportive performance. Ceylan (2005) dealt with the effects of gender and personality variables on using cognitive strategies in managing stress. This research indicated that there was a significant relation in the levels of using cognitive strategies to struggle with stress among the female and male athletes. Durmaz (2017) found a statistically significant difference in stress levels between women and men. Women's stress levels average score 80,56; while the average for men is 62.49. According to this, it is seen that women are more stressed than men.

The other findings showed that there were not any significant differences in the female wrestlers' stress levels in accordance with the variables of bachelor year, persons they live with and income status. But the female wrestlers' stress levels significantly differed when their family members interested in sport. However, Uluruh (2008) suggested that the high school students' viewpoints about stress-leading manager behaviours varied from the students' different personal and family characteristics.

Family has a great role for children to have tendencies for sport. In dissemination of sportive activities necessary for individuals' healthy development, significant tasks correspond to all education institutions, families at first. They must intend to canalize children in sport at a young age and lots of efforts must be made. Then our children are the future of our society and building stones, preparing them for social life in each aspect must be among the most important tasks for us (Hergüner, 1991).

As a result of these, providing opportunities to young athletes starting sport at an early age in order to show performance in sport away from stress, keep them away from stress affect athletes' individual performance at various levels, basic stress items leave negative marks on athletes' performance, so young athletes must be kept away from stressful environments. Family support in sport cannot be ignored, they must support their children when starting at sport and achieving in this field in future. 


\section{References}

Arık, A., 1996. Introduction to motivation and excitement. İstanbul: Çantay Bookstore. pp: 240-250.

Ayşen, P., 2015. Struggle with stress and stress in working life, Antalya Atatürk State hospital sample of nurses, institute of social sciences, Beykent University, İstanbul, 2015, s. 10. ( Unpublished Master's Thesis).

Bozkurt, T., M. Uluğ, C.A. Turpoglu, Z. Oktuğ, S. İçellioglu, M.S. Özden and Ö. Soysal, 2010. Stress. Istanbul: Istanbul Culture University.

Ceylan, M., 2005. "The influence of gender and personality variables on the use of cognitive strategies in stress management. Published Graduate Thesis, Ege Üniversity Health Sciences Institute Sporda Psycho Social Fields, İzmir.

Durmaz, E., 2017. An analysis of the effect of stress levels of labor on health staff: A hospital example. Published Graduate Thesis, İstanbul Gelişim University Social Sciences Institute, İstanbul.

Durmus, L. and M. Asçığlu, 2005. The effect of social isolation stress on learning in male Juvenile rats. Journal of Health Sciences, 14(1): 52-56. View at Google Scholar

Güçlü, N., 2001. Stress management. Gazi University Gazi Education Faculty Magazine, 21(1): 91-109.

Gülbeyaz, O., 2006. Organizational stress sources of administrators and teachers who work in boarding elementary schools and boarding primary schools. Published Graduate Thesis, İnönü Üniversity Institute of Social Sciences Educational Sciences Department.

Hergüner, G., 1991. The role of the family in the direction of the sport for the child and its importance. Ondokuz Mayıs Univ ersity Faculty of Education. 6: 87-91.

House, R.J. and J.R. Rizzo, 1972. Role conflict and ambiguity as critical variables in a model of organizational behavior. Organizational Behavior \& Human Performance, 7(3): 467-505. View at Google Scholar $\mid$ View at Publisher

Magnuson, J., 1990. Stress management. Journal of Property Management, 55(3): 74-79.

Makın, P.E. and P.A. Lindley, 1995. Positive stress management. İstanbul: Çev. Aysun Arslan, Rota Broadcast Production Promotion Trade Ltd.Sti. Publications.

Nesrin, Ü., 2016. Stress and management of hospital workers. Journal of Balkan and Near East Social Sciences, 2(2): 28-37.

Robins, S.P., 1996. Organizational behavior. 7th Edn., USA: Prentice Hall Inc.

Schermerborn, J.R., J.G. Hunt and R.N. Osborn, 1988. Managing organizational behavior. 3rd Edn., New York: John Wiley \& Sons, Inc.

Uluruh, A., 2008. Stress-generating manager behaviors and students' coping behaviors in secondary school students. Published Graduate Thesis, Dokuz Eylül Üniversity Department of Educational Sciences.

Yalçın, Y., 2009. The effect of sports satisfaction on the athletes' stress and aggression levels: An application in Antalya province to determine the role of coach gender. Published Graduate Thesis Erciyes University Social Sciences Institute Sports Management Department, Kayseri. 